University of Nebraska - Lincoln

DigitalCommons@University of Nebraska - Lincoln

Soil Property Changes during Conversion from Perennial Vegetation to Annual Cropping

\author{
Brian J. Wienhold \\ University of Nebraska-Lincoln, Brian.Wienhold@ars.usda.gov \\ Donald L. Tanaka \\ USDA-ARS, Don.Tanaka@ars.usda.gov
}

Follow this and additional works at: https://digitalcommons.unl.edu/usdaarsfacpub

Wienhold, Brian J. and Tanaka, Donald L., "Soil Property Changes during Conversion from Perennial Vegetation to Annual Cropping" (2001). Publications from USDA-ARS / UNL Faculty. 1218.

https://digitalcommons.unl.edu/usdaarsfacpub/1218

This Article is brought to you for free and open access by the U.S. Department of Agriculture: Agricultural Research Service, Lincoln, Nebraska at DigitalCommons@University of Nebraska - Lincoln. It has been accepted for inclusion in Publications from USDA-ARS / UNL Faculty by an authorized administrator of DigitalCommons@University of Nebraska - Lincoln. 
This article is a U.S. government work, and is not subject to copyright in the United States.

\title{
Soil Property Changes during Conversion from Perennial Vegetation to Annual Cropping
}

\author{
Brian J. Wienhold* and Donald L. Tanaka
}

\begin{abstract}
Management practices for conversion of land supporting perennial vegetation to crop production are needed. Effect of haying (hayed or not hayed), cropping (annual crop with no-tillage, minimum tillage, or conventional tillage, and no-tilled perennial crop), and $\mathbf{N}$ fertilization $\left(0\right.$ or $67 \mathrm{~kg} \mathrm{ha}^{-1}$ ) on soil properties were measured in 1995 and 1997 at a Conservation Reserve Program (CRP) site in North Dakota having an Amor loam (Fine-loamy, mixed, superactive, frigid, Typic Haplustoll) soil in a spring wheat (Triticum aestivum $\mathbf{L}$.), winter wheat, pea (Pisum sativum L.) rotation. Soil physical properties were not affected negatively by the management practices used. Haying and tillage practices influenced soil chemical properties. Organic $\mathrm{C}$ and total $\mathrm{N}$ content declined $\left(1.2 \mathrm{Mg} \mathrm{ha}^{-1}\right.$ for $\mathrm{C}$ and $0.1 \mathrm{Mg} \mathrm{ha}^{-1}$ for N) from 1995 to 1997. In hayed plots, organic $C$ and total $N$ increased as tillage intensity decreased while in non-hayed plots no pattern was observed. Haying and tillage influenced soil biological properties. Potentially mineralizable $\mathrm{N}$ at 0 to $0.05 \mathrm{~m}$ increased as tillage intensity decreased in 1997 . In the 0.05 - to $0.15-m$ depth, potentially mineralizable $\mathrm{N}$ increased from $1995\left(118 \mathrm{~kg} \mathrm{ha}^{-1}\right)$ to $1997\left(146 \mathrm{~kg} \mathrm{ha}^{-1}\right)$. By 1997 , soil properties in hayed plots responded to cropping practices similarly to those in established cropping systems in this region. In non-hayed plots, management induced patterns had not developed by 1997. Haying, conservation tillage, and annual cropping are viable approaches for converting land to annual crop production.
\end{abstract}

$\mathrm{T}$ HE UNITED STATES FOOD SECURITY ACT of 1985 established the Conservation Reserve Program (CRP) as a management program for conserving soil and water

B.J. Wienhold, USDA-ARS, Soil and Water Conservation Research Unit, Lincoln, NE 68583-0934; D.L. Tanaka, USDA-ARS, Northern Great Plains Research Lab., Mandan, ND 58554. Contribution of USDA-ARS and Univ. of Nebraska-Lincoln. Journal Ser. no. 13088. U.S. Department of Agriculture, Agriculture Research Service, Northern Plains Area, is an equal opportunity/affirmative action employer and all agency services are available without discrimination. Received 21 July 2000.*Corresponding author (BWIENHOLD1@ unl.edu).

Published in Soil Sci. Soc. Am. J. 65:1795-1803 (2001). resources by placing highly erodible land into perennial vegetation for 10 yr. Similar programs have been used historically in the USA to control erosion (e.g., soil bank program) and influence grain supplies. Programs encouraging producers to plant perennial vegetation on cropland to reduce grain surpluses are also used in Europe (Olaf Christen, 2000, personal communication).

Establishment of perennial vegetation on previously cropped lands reduces the potential for wind and water erosion and sequesters $\mathrm{C}$ in soil organic matter and vegetation. As CRP contracts expire, one option available to landowners is to return these lands to crop production. Over half of the land enrolled in CRP was located in the Great Plains. Management practices that maintain gains made in soil and water conservation and $\mathrm{C}$ sequestration during CRP years are needed by landowners returning these lands to crop production (Lindstrom et al., 1994).

Conversion of CRP land to crop production will require practices that manage the extensive vegetation residue that accumulated during the contract years prepare a seedbed that will allow crop establishment and production, and provide sufficient fertility to meet crop needs. Residue management can be accomplished through fire, tillage, or haying. Fire results in losses of $\mathrm{C}$ and $\mathrm{N}$ and may leave the soil susceptible to wind and water erosion. Cultivation has been shown to increase greatly the susceptibility of many soils to wind and water erosion (Low, 1972). Haying removes much of the aboveground biomass while leaving plant crowns and other residue as protection against wind and water erosion. Initially, as residues decompose, $\mathrm{N}$ mineralization or immobilization may occur, depending on the proportion of legumes present in the stand. Since $\mathrm{N}$ is the nutrient most commonly limiting crop production and added in greatest amounts by producers in the northern Great Plains, the effect of residue management on $\mathrm{N}$ availability is a major concern. 
Substantial work has been done in the northern Great Plains to develop conservation tillage practices and annual cropping rotations that replace the traditional conventionally tilled crop-fallow system. These more intensive systems make more efficient use of available water (Norwood, 1994; Peterson et al., 1996), reduce wind erosion, and are economically viable (Dhuyvetter et al., 1996). More intensive cropping has been shown to increase microbial activity and biomass (Biederbeck et al., 1984; Campbell et al., 1989; Wienhold and Halvorson, 1999), increase $\mathrm{N}$-mineralization rates (Biederbeck et al., 1984; Campbell et al., 1989; Janzen, 1987; Wienhold and Halvorson, 1998), and maintain higher soil organic C levels (Biederbeck et al., 1984; Campbell et al., 1995; Black and Tanaka, 1997) when compared to crop-fallow systems. Potential exists for the use of existing conservation tillage practices during conversion of land supporting perennial vegetation to annual cropping.

Tillage, $\mathrm{N}$ fertilization, and conversion from perennial vegetation to annual cropping will affect a number of physical, chemical, and biological soil properties. Tillage increases soil-residue contact by incorporating surface residue and creating a more oxidative environment (Doran, 1980). Adding $\mathrm{N}$ increases the amount of inorganic $\mathrm{N}$ available to microorganisms decomposing high $\mathrm{C}: \mathrm{N}$ residue. Replacement of perennial vegetation with annual crops alters the quality and quantity of residue added to the soil. Quantifying the magnitude and direction of change in these soil properties may serve as a way of rapidly assessing the effect various management practices have on the soil during CRP conversion. In 1994, a study was initiated to compare changes in soil properties under various haying, tillage, and $\mathrm{N}$ fertilization practices with those under perennial vegetation at a CRP site in North Dakota. The objective of the study was to identify practices that can be used to convert sites under perennial vegetation to annual cropping without degrading physical, chemical, or biological soil properties.

\section{MATERIALS AND METHODS Study Site}

The research site was located in Morton County, North Dakota, $\left(46^{\circ} 46^{\prime} \mathrm{N} 100^{\circ} 50^{\prime} \mathrm{W}\right.$, elevation $549 \mathrm{~m}$ above sea level) approximately $20 \mathrm{~km}$ southwest of the city of Mandan. Soil at the site was an Amor loam (Fine-loamy, mixed, superactive, frigid, Typic Haplustoll) with slopes of 9 to $15 \%$. While soil properties and crop response are affected by topographic position and slope (Jenny, 1980) the objective of this study was not to determine the effect of topography and slope on soil properties and crop response. Hence, this study used blocking in the experimental design and soil sampling strategies to control variation associated with topography and slope. Blocks were located across the slope of the study site such that each block was homogenous in terms of slope and topographic features. Within each block soil was collected from a similar slope position area of each plot. This sampling strategy was used to minimize confounding of treatment effects with topographic effects on soil properties.

Annual precipitation has been highly variable and averages $410 \mathrm{~mm}$ with $60 \%$ typically received during the growing season. Average annual temperature is $4{ }^{\circ} \mathrm{C}$ and daily averages range from a maximum of $21^{\circ} \mathrm{C}$ during the summer to a minimum of $-11^{\circ} \mathrm{C}$ during the winter.

The field was enrolled in CRP and seeded with alfalfa (Medicago sativa L.) and wheatgrass (Agropyron spp.) in 1989. The initial seeding did not establish well and the site was reseeded in 1991. In the fall of 1994, a cropping practice by $\mathrm{N}$-rate experiment was initiated with half of the plots being hayed and half of the plots not hayed prior to the initial tillage. Haying of the main plots was done on 11 Oct. 1994 and removed $4500 \mathrm{~kg} \mathrm{ha}^{-1}$ of biomass. The initial tillage and herbicide applications was done on 14 Oct. 1994. The experimental design was a randomized complete block with a splitsplit plot treatment arrangement. The experiment was blocked across soils to control potential variation in results caused by differences in slope and topographic position. Hayed and nonhayed treatments served as the whole plot treatments; cropping treatment, annual crop with conventional tillage (CT), annual crop with minimum tillage (MT), annual crop with notillage (NT), and perennial vegetation with no-tillage, as the split plot treatment; and $\mathrm{N}$ rate, 0 and $67 \mathrm{~kg} \mathrm{~N} \mathrm{ha}^{-1}$ as $\mathrm{NH}_{4} \mathrm{NO}_{3}$ surface applied prior to spring tillage, as the split-split plot treatment. The plots in perennial vegetation with no-tillage served as reference plots. The experiment was replicated four times. Whole plots were 27 by $30 \mathrm{~m}$, split plots were 9 by $30 \mathrm{~m}$, and split-split plots were 9 by $15 \mathrm{~m}$. These plots were of sufficient size to allow use of commercial field scale equipment for all operations. Conventional tillage utilized an undercutter (sweep plow), a chisel plow, and a double disk in the fall and spring to control weeds and incorporate crop residue. Minimum tillage utilized one or two passes with an undercutter in the spring and herbicides to control weeds. No-tillage relied on herbicides for weed control. Surface residue cover at planting averaged $<30 \%$ with $\mathrm{CT}$, between 30 and $60 \%$ with MT, and $>60 \%$ with NT. Spring wheat was planted 12 June 1995, winter wheat was planted 3 Oct. 1995, and pea was planted 9 May 1997. Seeding was done using a Haybuster no-tillage drill (Duratech Industries International, Jamestown, ND) ${ }^{1}$.

\section{Soil Sampling and Laboratory Methods}

In the spring of 1995 and 1997, soil samples were collected from the 0- to 0.05- and 0.05- to 0.15-m depths of each plot. Within each block soil was collected from a similar slope position area of each plot. These soil samples were collected prior to fertilizer application each year and represent conditions 1 to $2 \mathrm{wk}$ prior to seeding. Soils were passed through a 4-mm sieve to remove root material, soil mass was recorded, and moisture content was determined. Soils were stored at $-5^{\circ} \mathrm{C}$ until biological attributes were assessed. After assessment of biological attributes the remaining soil was passed through a $2-\mathrm{mm}$ sieve, air-dried, ground, and used for chemical analysis.

Bulk density, water content, and water-filled pore space, were the physical soil attributes measured. Bulk density was calculated by dividing the mass of soil, corrected for moisture content, by the volume of soil collected (Blake and Hartge, 1986). Soil volume was determined by measuring the dimensions of the soil pit excavated in each plot. Water content was determined gravimetrically (Lowery et al., 1996). Water-filled pore space was calculated by means of the measured bulk density and water content values and assuming a particle density of $2.65 \mathrm{~g} \mathrm{~cm}^{-3}$ (Arshad et al., 1996).

Total organic $\mathrm{C}$, total $\mathrm{N}$, inorganic $\mathrm{N}, \mathrm{pH}$, and electrical

\footnotetext{
${ }^{1}$ Mention of trade names or proprietary products does not indicate endorsement by USDA and does not imply its approval to the exclusion of other products that may be suitable.
} 
conductivity (EC) were chosen as chemical attributes of soil quality. Total $\mathrm{N}$ and $\mathrm{C}$ were determined by dry combustion with a Carlo-Erba NA 1500 NCS (Carlo Erba Instruments, Milan, Italy) analyzer (Schepers et al., 1989). Total organic C concentration was determined by correcting total $\mathrm{C}$ concentrations for carbonate content when soil $\mathrm{pH}$ was greater than 7.2. Inorganic $\mathrm{N}$ was measured in $0.01 \mathrm{M} \mathrm{CaCl}_{2}(10 \mathrm{~g}$ of soil in $100 \mathrm{~mL}$ of solution) extracts colorimetrically with a Lachat flow-through ion analyzer (Zellweger Analytics, Lachat Instruments Div., Milwaukee, WI). Nitrate-N was determined by the $\mathrm{Cd}$ reduction method and $\mathrm{NH}_{4}^{+}-\mathrm{N}$ was determined by the Indophenol blue method (Mulvaney, 1996). Distilled water was added (1:1 on a gravimetric basis) to $10 \mathrm{~g}$ of air-dried soil and $\mathrm{pH}$ determined with a glass electrode (McLean, 1982). The soil slurry was then filtered and EC determined with a conductivity meter (Rhoades, 1982).

Biological soil quality attributes assessed included: N-mineralization; numbers of culturable fungi, bacteria, and actinomycetes; and microbial biomass $\mathrm{C}$ and $\mathrm{N}$. Nitrogen mineralization rate was determined by a laboratory incubation method similar to that described by Stanford and Smith (1972). Silica sand and $15 \mathrm{~g}$ of soil were added together in equal amounts and thoroughly mixed. The mixture was transferred to a glass leaching tube and glass wool was placed on the soil surface to prevent dispersion of the sample during leaching. The substrate was slightly compacted and leached with $100 \mathrm{~mL}$ of 0.01 $M \mathrm{CaCl}_{2}$ under a suction of $0.7 \mathrm{MPa}$ to remove mineral $\mathrm{N}$. Leachate was brought to $100 \mathrm{~mL}$ with $0.01 \mathrm{M} \mathrm{CaCl}_{2}$. The leaching tube was covered with Parafilm (American National Can, Greenwich, CT). A hole was made in the Parafilm to ensure aeration. Leaching tubes were weighed and stored upright in an incubator at $35^{\circ} \mathrm{C}$. Tubes were reweighed weekly and weight adjusted with distilled water. Every 2 wk tubes were leached with $100 \mathrm{~mL}$ of $0.01 M \mathrm{CaCl}_{2}$ and returned to the incubator. Tubes were incubated for a total of $8 \mathrm{wk}$. Leachates were stored at $-5^{\circ} \mathrm{C}$ until they could be analyzed for inorganic $\mathrm{N}$ content $(<60 \mathrm{~d})$. Inorganic $\mathrm{N}$ content of leachate was determined by quickly thawing the samples and determining $\mathrm{NH}_{4}^{+}-\mathrm{N}$ and $\mathrm{NO}_{2}^{-2}-\mathrm{N}$ plus $\mathrm{NO}_{3}^{-}-\mathrm{N}$ content by automated colorimetric analysis with a Lachat flow-through ion analyzer (Zellweger Analytics, Lachat Instruments Div., Milwaukee, WI).

Fungi, bacteria, and actinomycete numbers were determined by plating a serial dilution of a soil-water suspension on selective media. Bacteria were grown out on tryptic soy agar, actinomycetes were grown out on starch-casein agar, and fungi were grown on Martin's Rose Bengal agar (Wollum, 1982). Plates were incubated at $27^{\circ} \mathrm{C}$ for $10 \mathrm{~d}$ and visible colonies counted.

Microbial biomass $\mathrm{N}$ and $\mathrm{C}$ were determined using the chloroform fumigation extraction method as modified by Bruulsema and Duxbury (1996). Duplicate soil samples equivalent to $25 \mathrm{~g}$ oven-dried soil were placed in $50-\mathrm{mL}$ beakers and sufficient distilled water added to bring the soil to approximately $60 \mathrm{~m}^{3} \mathrm{~m}^{-3}$ water-filled pore space. One soil sample, designated as the control, was placed in a desiccator lined with moist paper towels. The second soil sample, designated as the fumigated sample, was placed in a second desiccator also lined with moist paper towels. Both desiccators were placed in an incubator at $25^{\circ} \mathrm{C}$ for $10 \mathrm{~d}$. Fumigation was accomplished by placing a beaker containing $50 \mathrm{~mL}$ of purified $\mathrm{CHCl}_{3}$ (Jenkinson and Powlson, 1976) in the appropriate desiccator and evacuating the desiccator until the $\mathrm{CHCl}_{3}$ boiled. The desiccator was returned to the incubator for $24 \mathrm{~h}$. Both fumigated and nonfumigated soils were extracted with $50 \mathrm{~mL}$ of $0.05 \mathrm{M} \mathrm{K}_{2} \mathrm{SO}_{4}$. Extracts were filtered into plastic bottles and stored at $-5^{\circ} \mathrm{C}$ until analyzed for $\mathrm{C}$ and N. Extracts were thawed and $0.5 \mathrm{~mL}$ (as five $0.1-\mathrm{mL}$ increments allowing the solution to evaporate between additions) added to tin cups. The tin cups were carefully crushed to avoid loss of crystals and $\mathrm{C}$ and $\mathrm{N}$ concentrations determined with a Carlo-Erba NA 1500 NCS analyzer (Carlo Erba Instruments, Milan, Italy).

Soil attributes were compared among treatments by a repeated measures split-split plot model in PROC MIXED of SAS (Littell et al., 1996). Differences were declared significant at 0.05 probability level. Results are reported as treatment means and differences among means were determined by pairwise comparisons made with the DIFF option of the LSMEANS statement. Pearson correlation coefficients were calculated to test the correlation among physical, chemical, and biological attributes in this study.

\section{RESULTS AND DISCUSSION Physical Attributes}

In the 0 - to $0.05-\mathrm{m}$ depth, bulk density exhibited a pretillage haying $\times$ cropping practice interaction. In hayed treatments, bulk density was lower with $\mathrm{CT}$ than with MT and NT while bulk density in hayed reference treatments was similar to that in the three annually cropped treatments (Table 1 ). In non-hayed treatments, bulk density was similar among the annual cropping treatments but was lower in NT than in reference treatments. Bulk density in the $0.05-$ to $0.15-\mathrm{m}$ depth responded to pretillage haying and cropping practices similarly to that in the 0 - to $0.05-\mathrm{m}$ depth but higher within treatment variation resulted in no significant differences using analysis of variance (Table 1). Pretillage haying and tillage did not result in compaction problems at this site as observed bulk densities were below $1.65 \mathrm{~g} \mathrm{~cm}^{-3}$ which would restrict root penetration (Arshad et al., 1996). Observed bulk densities were much lower than those commonly reported for cropped soil and are the result of the large root biomass that accumulated during the years the site supported perennial vegetation.

Water content exhibited a year $\times$ pretillage haying treatment $\times$ cropping practice interaction in both depths. In 1995, water content in the 0- to 0.05-m depth was similar across cropping treatments that had been hayed prior to tillage and was higher in the NT treatment than in the other cropping treatments that had not been hayed prior to tillage (Table 2). In 1997, water content

Table 1. Soil bulk density in the 0 - to $0.05-\mathrm{m}$ depth averaged across years and $\mathbf{N}$ fertilizer treatments as a function of cropping practice and pre-tillage haying.

\begin{tabular}{|c|c|c|c|c|}
\hline \multirow[b]{2}{*}{ Haying treatment } & \multicolumn{4}{|c|}{ Cropping practice $\dagger$} \\
\hline & CT & MT & NT & Reference \\
\hline & & o t & $5 \mathrm{~m}$ & \\
\hline \multirow{3}{*}{$\begin{array}{l}\text { Hayed } \\
\text { Non-hayed }\end{array}$} & $0.64 a$ I & $0.92 \mathrm{~b}$ & $\overline{1.00 b}$ & 0.82ab \\
\hline & $0.79 \mathrm{ab}$ & $0.80 \mathrm{ab}$ & $0.66 a$ & $0.93 b$ \\
\hline & \multicolumn{4}{|c|}{0.05 to $0.15 \mathrm{~m}$} \\
\hline Hayed & $1.08 \S$ & 1.21 & 1.33 & 1.12 \\
\hline Non-hayed & 1.18 & 1.38 & 1.09 & 1.17 \\
\hline
\end{tabular}

† CT annual cropping with conventional tillage, MT annual cropping with minimum tillage, NT annual cropping with no-tillage, reference maintained in perennial vegetation.

$\S$ Means are not significantly different at $P=\mathbf{0 . 0 5}$.

II Haying by cropping practice interaction $(P=0.006)$. Means within a row followed by a different letter are significantly different at $P=0.05$. 
Table 2. Soil moisture attributes averaged across $\mathbf{N}$ fertilizer treatments as a function of year, pre-tillage haying, and cropping practice.

\begin{tabular}{|c|c|c|c|c|c|c|c|c|c|}
\hline \multirow[b]{2}{*}{ Haying treatment } & \multirow[b]{2}{*}{ Year } & \multicolumn{8}{|c|}{ Cropping practice $\dagger$} \\
\hline & & CT & MT & NT & Reference & CT & MT & NT & Reference \\
\hline & & \multicolumn{4}{|c|}{ Water content $\left(\mathrm{g} \mathrm{g} \mathrm{g}^{-1}\right)$} & \multicolumn{4}{|c|}{ Water filled pore space $\left(\mathrm{m}^{3} \mathrm{~m}^{-3}\right)$} \\
\hline & & & & & 0 to $0.05 \mathrm{~m}$ & & & & \\
\hline \multirow{2}{*}{ Hayed } & 1995 & $0.27 \mathrm{a}$ II & $0.29 \mathrm{a}$ & $0.27 \mathbf{a}$ & $\overline{0.28 a}$ & $0.23 a+$ & $0.42 b$ & $0.45 b$ & $0.42 \mathrm{~b}$ \\
\hline & 1997 & $0.25 \mathrm{a}$ & $0.26 a$ & $0.27 a$ & $0.27 \mathbf{a}$ & $0.22 \mathrm{a}$ & $0.39 b$ & $0.43 b$ & $0.39 \mathrm{~b}$ \\
\hline \multirow[t]{3}{*}{ Non-hayed } & 1995 & $0.30 \mathrm{ab}$ & $0.28 \mathrm{a}$ & $0.31 b$ & $0.28 \mathrm{a}$ & $0.34 a$ & $0.32 \mathrm{a}$ & $0.28 \mathrm{a}$ & 0.33a \\
\hline & 1997 & $0.26 \mathrm{a}$ & $0.26 a$ & $0.26 a$ & $0.31 b$ & 0.30ab & $0.29 \mathrm{ab}$ & $0.24 a$ & $0.38 \mathrm{~b}$ \\
\hline & & & & & 0.05 to $0.15 \mathrm{~m}$ & & & & \\
\hline \multirow[t]{2}{*}{ Hayed } & 1995 & $0.24 a \S$ & $0.23 a$ & $0.24 a$ & $0.23 a$ & $0.45 \mathrm{a} ¥$ & $0.52 a b$ & $0.64 \mathrm{~b}$ & 0.48ab \\
\hline & 1997 & $0.21 \mathrm{a}$ & $0.22 a$ & $0.23 \mathbf{a}$ & $0.21 a$ & $0.39 a$ & $0.51 \mathbf{a b}$ & $0.63 b$ & $0.44 a$ \\
\hline \multirow[t]{2}{*}{ Non-hayed } & 1995 & $0.24 a$ & $0.24 a$ & $0.24 a$ & $0.23 a$ & $0.55 \mathrm{a}$ & $0.74 b$ & $0.47 \mathbf{a}$ & $0.46 a$ \\
\hline & 1997 & $0.21 a$ & $0.22 a$ & $0.21 a$ & $0.26 \mathrm{~b}$ & $0.47 a$ & $0.68 \mathrm{~b}$ & $0.41 a$ & $0.51 a$ \\
\hline
\end{tabular}

$\dagger$ CT annual cropping conventional tillage, MT annual cropping minimum tillage, NT annual cropping no-tillage, reference maintained in perennial vegetation.

+ Year by haying by cropping practice interaction $(P=0.0001)$. Means within a row followed by a different letter are significantly different at $P=0.05$. $\S$ Year by haying by cropping practice interaction $(P=0.007)$. Means within a row followed by a different letter are significant different at $P=0.05$.

II Year by haying by cropping practice interaction $(P=0.001)$. Means within a row followed by a different letter are significantly different at $P=0.05$. $¥$ Year by haying by cropping practice interaction $(P=\mathbf{0 . 0 0 4})$. Means within a row followed by a different letter are significantly different at $P=0.05$.

was similar across cropping treatments that had been hayed and was higher in reference plots than in annually cropped treatments that had not been hayed (Table 2). Water content in the 0.05 - to $0.15-\mathrm{m}$ depth exhibited a year $\times$ pretillage haying $\times$ cropping practice interaction. In 1995 , water contents in the $0.05-$ to $0.15-\mathrm{m}$ depth were similar across cropping treatments in both hayed and non-hayed treatments (Table 2). In 1997, water content was similar across cropping practice treatments that had been hayed and was greater in the reference treatment than in the annually cropped treatments that had not been hayed (Table 2).

Surface residue acts as a boundary layer through which heat and water must pass during exchange between the soil and the atmosphere. Doran (1980) reported that as tillage intensity decreased, soil temperatures were lower and soil was more moist. After 2 yr of cropping or haying, water content in both soil depths was higher in the non-hayed reference treatment than in the hayed reference treatment and hayed and nonhayed annually cropped treatments. The large amount of residue in the non-hayed reference treatment likely trapped more snow during the winter and reduced evaporation when compared with the other treatments.

Water-filled pore space exhibited a year $\times$ pretillage haying $\times$ cropping practice interaction in both depths (Table 2). In the 0- to 0.05-m depth in 1995, water-filled pore space was lower in the CT treatment than in the other cropping practice treatments that had been hayed and was similar across cropping practices that had not been hayed (Table 2). In 1997, water-filled pore space was lower in the CT treatment than in the other cropping practice treatments that had been hayed. In non-hayed treatments water-filled pore space was similar across the annually cropped treatments and was greater in the reference treatment than in the NT treatment (Table $2)$. In the $0.05-$ to $0.15-\mathrm{m}$ depth water-filled pore space in 1995 was greater in the NT treatment than in the CT treatment and was similar across the MT, NT, and reference treatments that had been hayed. In the nonhayed treatment water-filled pore space was greater in the MT treatment than in other cropping practices (Ta- ble 2). In 1997, water-filled pore space was greater in the NT treatment than in the CT treatment and was similar among the reference, MT, and CT treatments that had been hayed. In the non-hayed treatment waterfilled pore space was greater in the MT treatment than in the other cropping practice treatments (Table 2). Water-filled pore space is influenced by bulk density. Differences among treatments in water-filled pore space reflect treatment effects on bulk density. While waterfilled pore space was affected by pretillage haying and tillage treatments, values were always within the range indicative of aerobic soils (Linn and Doran, 1984).

While the management practices used in this study influenced the soil physical properties measured, none of the changes would suggest a degradation in soil physical condition. These results support those of an earlier study where we compared surface infiltration rates among the treatments at this site (Wienhold and Tanaka, 2000). While tillage and haying effects on infiltration rates were detected after initial treatment in 1995, we found no change between 1995 and 1997 in the cropped plots and concluded that none of the management practices used in this study had a detrimental influence on soil physical properties which affect infiltration (Wienhold and Tanaka, 2000).

\section{Chemical Attributes}

In the 0 - to $0.05-\mathrm{m}$ depth, both $\mathrm{NH}_{4}^{+}-\mathrm{N}^{-}$and $\mathrm{NO}^{-}{ }_{3}-\mathrm{N}$ content exhibited year $\times$ pretillage haying $\times$ cropping practice interactions. In 1995 , the $\mathrm{NH}_{4}^{+}-\mathrm{N}$ content was lower in the CT treatment than in the other cropping practice treatments that were hayed and were similar across cropping practice treatments that were not hayed (Table 3). In 1997, the $\mathrm{NH}_{4}^{+}-\mathrm{N}$ content was greater in the reference treatment than in the other cropping practice treatments that were hayed and was lower in the CT treatment than in the other cropping practice treatments that were not hayed (Table 3). In 1995, the $\mathrm{NO}_{3}^{-}-\mathrm{N}$ content was similar among all cropping practices in both hayed and non-hayed treatments (Table 3). In 1997, $\mathrm{NO}_{3}^{-}-\mathrm{N}$ content was lower in the hayed $\mathrm{CT}$ treatment 
Table 3. Inorganic $\mathbf{N}$ content averaged across $\mathbf{N}$ fertilizer treatments as a function of year, pre-tillage haying, and cropping practice.

\begin{tabular}{|c|c|c|c|c|c|c|c|c|c|}
\hline \multirow[b]{2}{*}{ Haying treatment } & \multirow[b]{2}{*}{ Year } & \multicolumn{8}{|c|}{ Cropping practice $\dagger$} \\
\hline & & CT & MT & NT & Reference & CT & MT & NT & Reference \\
\hline & & \multicolumn{8}{|c|}{0 to $0.05 \mathrm{~m}$} \\
\hline & & & - NH & $\left.\mathrm{g} \mathrm{ha}^{-1}\right)$ & 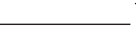 & - & - NO & $\left.\mathrm{g} \mathrm{ha}^{-1}\right)$ & \\
\hline \multirow[t]{2}{*}{ Hayed } & 1995 & $0.76 a$ af & $2.01 \mathrm{~b}$ & $1.99 \mathrm{~b}$ & $2.96 \mathrm{~b}$ & $4.53 a \ddagger$ & $4.40 \mathrm{a}$ & $4.59 \mathrm{a}$ & 3.37a \\
\hline & 1997 & $0.18 a$ & $0.53 a$ & $0.19 \mathrm{a}$ & $2.70 \mathrm{~b}$ & $3.06 a$ & $6.20 \mathrm{~b}$ & $6.92 \mathrm{~b}$ & $7.23 \mathrm{~b}$ \\
\hline \multirow[t]{4}{*}{ Non-hayed } & 1995 & $2.93 a$ & $1.86 a$ & $2.50 \mathrm{a}$ & $1.97 \mathbf{a}$ & $5.20 \mathrm{a}$ & $4.79 \mathrm{a}$ & $5.28 \mathrm{a}$ & $6.09 \mathrm{a}$ \\
\hline & 1997 & $0.38 \mathrm{a}$ & $0.95 b$ & $0.71 b$ & $1.97 \mathrm{~b}$ & $5.94 a$ & $5.49 \mathrm{a}$ & $3.87 \mathrm{a}$ & $4.58 \mathrm{a}$ \\
\hline & & \multicolumn{8}{|c|}{0.05 to $0.15 \mathrm{~m}$} \\
\hline & & $\longrightarrow$ & $-\mathrm{NH}$ & $\left.\mathbf{g ~ h a}^{-1}\right)$ & 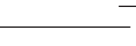 & 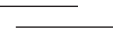 & - NO & $\left.\mathbf{g ~ h a}^{-1}\right)-$ & \\
\hline \multirow[t]{2}{*}{ Hayed } & 1995 & $3.65 \mathrm{a} \S$ & 3.44a & 5.38a & 3.76a & 6.13ab¥ & 5.30ab & $6.68 b$ & 2.97a \\
\hline & 1997 & $0.55 a$ & 1.53ab & $0.53 a$ & $2.02 b$ & 7.08ab & $10.13 b$ & $11.91 b$ & $4.65 \mathrm{a}$ \\
\hline \multirow[t]{2}{*}{ Non-hayed } & 1995 & $4.37 a$ & $4.36 a$ & $6.40 \mathrm{~b}$ & $1.70 \mathrm{c}$ & $5.79 a$ & $6.59 a$ & $6.56 a$ & 3.52a \\
\hline & 1997 & $0.29 \mathrm{a}$ & $1.30 \mathrm{a}$ & $0.89 a$ & $2.91 \mathrm{~b}$ & $9.90 a$ & 11.10a & 7.82ab & $4.37 \mathrm{~b}$ \\
\hline
\end{tabular}

$\dagger$ CT annual cropping conventional tillage, MT annual cropping minimum tillage, NT annual cropping no-tillage, reference maintained in perennial vegetation.

$\leftarrow$ Year by haying by cropping practice interaction $(P=0.02)$. Means within a row followed by a different letter are significantly different at $P=0.05$. $\$$ Year by haying by cropping practice interaction $(P=0.05$. Means within a row followed by a different letter are significantly different at $P=0.05$. II Year by haying by cropping practice interaction $(P=0.02)$. Means within a row followed by a different letter are significantly different at $P=0.05$. $¥$ Year $(P=\mathbf{0 . 0 0 0 1})$, cropping practice $(P=\mathbf{0 . 0 0 0 6})$. Means within a row followed by a different letter are significantly different at $P=0.05$.

than in the other cropping practice treatments that were hayed and was similar among cropping practice treatments in the non-hayed treatment (Table 3).

In the 0.05 - to 0.15 -m depth, $\mathrm{NH}_{4}^{+}-\mathrm{N}$ content exhibited a year $\times$ pretillage haying $\times$ cropping practice interaction. In 1995, $\mathrm{NH}_{4}^{+}-\mathrm{N}$ content was similar across cropping practice treatments in the hayed treatment and in the non-hayed treatment increased in the order reference $<\mathrm{CT}$ and MT $<$ NT (Table 3 ). In the 0.05- to $0.15-\mathrm{m}$ depth, $\mathrm{NO}_{3}^{-}-\mathrm{N}$ content exhibited year and cropping practice effects. Nitrate-N content increased from 1995 to 1997 and across cropping practices increased in the order reference $<\mathrm{CT}<\mathrm{MT}$ and NT (Table 3 ).

Soil chemical properties were altered by the management practices used in this study. Conversion from perennial vegetation to annual crops and tillage altered the form and amount of inorganic $\mathrm{N}$ present. Under aerobic conditions, $\mathrm{NO}_{3}^{-}-\mathrm{N}$, as observed in both soil depths, should be the dominant form of soil inorganic $\mathrm{N}$. Under perennial grass it is not unusual to find $\mathrm{NH}_{4}^{+}-\mathrm{N}$ amounts higher than in cropped soils (Prasad and Power, 1997). This is consistent with the observed decrease in $\mathrm{NH}_{4}^{+}-\mathrm{N}$ content in cropped plots from 1995 (year of conversion) to 1997 (after 2 yr of cropping). The strong positive correlation between water content and $\mathrm{NH}_{4}^{+}-\mathrm{N}$ content at the time of sampling in both soil depths $(R=0.85$ in the 0 - to $0.05-\mathrm{m}$ depth and $R=$ 0.82 in the $0.05-$ to $0.15-\mathrm{m}$ depth) is likely due to an increase in anaerobic microsites where $\mathrm{NH}_{4}^{+}-\mathrm{N}$ could exist within the profile as water content increases. The increase in $\mathrm{NO}_{3}^{-}-\mathrm{N}$ content in cropped plots from 1995 to 1997 is likely the result of mineralization of plant residue and an increase in the activity of nitrifying bacteria.

The inorganic $\mathrm{N}$ contents in reference plots were similar to those observed in cropped plots in 1995 and changed little from 1995 to 1997 suggesting that $\mathrm{N}$ transformations in soil with perennial vegetation were near a steady state condition. While the inorganic $\mathrm{N}$ levels measured in cropped soils in this study increased from 1995 to 1997, they are lower than those observed in soil from a nearby annual cropping system that had been cropped for more than 16 years (Wienhold and Halvorson, 1998). The low inorganic $\mathrm{N}$ levels present in the cropped plots, lack of an $\mathrm{N}$ treatment effect on any of the chemical properties measured, and a lack of a $\mathrm{N}$ fertilizer response by the crops (unpublished data) suggests that much of the added $\mathrm{N}$ was being immobilized by soil microbes decomposing the high $\mathrm{C}: \mathrm{N}$ residue present when the site conversion was initiated (Stevenson, 1986). Wienhold and Halvorson (1998) also observed that as tillage intensity declined inorganic $\mathrm{N}$ levels increased, a pattern emerging in the hayed plots of this study (Table 3). As the residue in the non-hayed plots decomposes we expect a similar pattern to emerge in these plots as well.

Organic C content declined from $11.8 \mathrm{Mg} \mathrm{ha}^{-1}$ in 1995 to $10.5 \mathrm{Mg} \mathrm{ha}^{-1}$ in $1997(P=0.001)$ and total $\mathrm{N}$ declined from $1.02 \mathrm{Mg} \mathrm{ha}^{-1}$ in 1995 to $0.96 \mathrm{Mg} \mathrm{ha}^{-1}$ in $1997(P=$ 0.02 ) in the 0 - to $0.05-\mathrm{m}$ depth. In addition, organic $\mathrm{C}$ and total $\mathrm{N}$ content exhibited a pretillage haying $\times$ cropping practice interaction in the 0 - to $0.05-\mathrm{m}$ depth (Table 4). Organic $\mathrm{C}$ and total $\mathrm{N}$ content was lower in the hayed CT treatment than the other hayed treatments and was similar across cropping practices in the nonhayed treatment (Table 4). In the 0.05- to 0.15-m depth organic $\mathrm{C}$ and total $\mathrm{N}$ content exhibited a pretillage haying $\times$ cropping practice interaction. Organic $\mathrm{C}$ and total $\mathrm{N}$ content was lower in the $\mathrm{CT}$ cropping practice and greatest in the NT cropping practice of the hayed treatment and was greatest in the MT cropping practice of the non-hayed treatment (Table 4). Organic C content in the 0 - to $0.15-\mathrm{m}$ depth decreased from $35.3 \mathrm{Mg}$ $\mathrm{ha}^{-1}$ in 1995 to $34.0 \mathrm{Mg} \mathrm{ha}^{-1}$ in $1997(P=0.04)$. In the 0 - to $0.15-\mathrm{m}$ depth organic $\mathrm{C}$ and total $\mathrm{N}$ content exhibited a pretillage haying $\times$ cropping practice interaction (Table 4). Organic C and total N content was lower in the CT cropping practice than in the other three cropping practices of the hayed treatments and was lower in the NT cropping practice than the other three cropping practices of the non-hayed treatment (Table 4).

Conversion from perennial grass-legume vegetation 
Table 4. Organic $\mathbf{C}$ and total $\mathbf{N}$ content averaged over years and $\mathbf{N}$ fertilizer treatments as a function of pre-tillage haying and cropping practice.

\begin{tabular}{|c|c|c|c|c|c|c|c|c|}
\hline \multirow[b]{2}{*}{ Haying treatment } & \multicolumn{8}{|c|}{ Cropping practice $\dagger$} \\
\hline & CT & MT & NT & Reference & CT & MT & NT & Reference \\
\hline & \multicolumn{4}{|c|}{ - Organic $\mathrm{C}\left(\mathrm{Mg} \mathrm{ha}^{-1}\right)$} & \multicolumn{4}{|c|}{ Total N $\left(\mathrm{Mg} \mathrm{ha}^{-1}\right)$} \\
\hline & \multicolumn{4}{|c|}{0 to $0.05 \mathrm{~m}$} & \multicolumn{4}{|c|}{0 to $0.05 \mathrm{~m}$} \\
\hline Hayed & 8.4aII & 13.1b & 12.6b & $12.5 \mathrm{~b}$ & $0.75 a ¥$ & $1.16 \mathrm{~b}$ & 1.14b & $1.12 \mathrm{~b}$ \\
\hline \multirow{2}{*}{ Non-hayed } & 11.4a & 10.1a & 9.6a & 11.5a & $0.98 \mathrm{a}$ & $0.90 \mathrm{a}$ & $0.84 a$ & 1.02a \\
\hline & \multicolumn{4}{|c|}{0.05 to $0.15 \mathrm{~m}$} & \multicolumn{4}{|c|}{0.05 to $0.15 \mathrm{~m}$} \\
\hline \multirow{3}{*}{$\begin{array}{l}\text { Hayed } \\
\text { Non-hayed }\end{array}$} & 21.6a§ & 23.9ab & 26.1b & 22.7ab & $1.91 \mathrm{a}+\dagger$ & 2.13ab & $2.36 \mathrm{~b}$ & 2.02ab \\
\hline & $22.5 a$ & $28.2 \mathrm{~b}$ & 20.9a & 22.2a & $2.00 \mathrm{a}$ & $2.50 \mathrm{~b}$ & $1.86 a$ & 2.03a \\
\hline & \multicolumn{4}{|c|}{0 to $0.15 \mathrm{~m}$} & \multicolumn{4}{|c|}{0 to $0.15 \mathrm{~m}$} \\
\hline Hayed & $30.0 \mathrm{a}+$ & $37.0 \mathrm{~b}$ & 38.8b & 35.3ab & $2.66 \mathrm{a}+\mathrm{t}$ & $3.29 \mathrm{~b}$ & $3.50 \mathrm{~b}$ & $3.14 b$ \\
\hline Non-hayed & 33.8ab & 38.3b & 30.5a & 33.8ab & 2.99ab & $3.39 \mathrm{~b}$ & 2.70a & 3.05ab \\
\hline
\end{tabular}

$\dagger$ CT annual cropping conventional tillage, MT annual cropping minimum tillage, NT annual cropping no-tillage, reference maintained in perennial vegetation.

+ Haying by cropping practice interaction $(P=0.02)$. Means within a row followed by a different letter are significantly different at $P=0.05$.

$\S$ Haying by cropping practice interaction $(P=\mathbf{0 . 0 3})$. Means within a row followed by a different letter are significantly different at $P=0.05$.

II Haying by cropping practice interaction $(P=\mathbf{0 . 0 0 0 3})$. Means within a row followed by a different letter are significantly different at $P=0.05$.

$¥$ Haying by cropping practice interaction $(P=0.0005)$. Means within a row followed by a different letter are significantly different at $P=0.05$.

$\dagger$ Haying by cropping practice interaction $(P=\mathbf{0 . 0 2})$. Means within a row followed by a different letter are significantly different at $P=0.05$.

+ Haying by cropping practice interaction $(P=0.009)$. Means within a row followed by a different letter are significantly different at $P=0.05$.

to an annual cropping system resulted in the loss of 1.25 $\mathrm{Mg} \mathrm{ha}^{-1}$ of $\mathrm{C}$ from the 0 - to $0.05-\mathrm{m}$ depth of these soils after two growing seasons. Biomass inputs under annual cropping were not sufficient to maintain $\mathrm{C}$ under any of the management strategies used in this study when compared to maintaining the perennial vegetation. Organic $\mathrm{C}$ and total $\mathrm{N}$ contents were highly correlated in both soil depths $(R=0.98$ in the 0 - to $0.05-\mathrm{m}$ depth and $R=0.99$ in the $0.05-$ to $0.15-\mathrm{m}$ depth) and responded similarly to pretillage haying and tillage (Table 4). Pretillage haying removed $4500 \mathrm{~kg} \mathrm{ha}^{-1}$ of aboveground biomass and also likely initiated senescence and decomposition of below ground biomass. In non-hayed plots the vegetation would have remained physiologically active until tillage or herbicide application occurred and larger amounts of biomass remained on these plots when cropping was initiated. Tillage incorporates surface residue making it more available to soil microorganisms by increasing soil-residue contact, mixes the soil reducing the degree of stratification in organic matter that may have been present, and creates a more oxidative environment (Doran, 1980). The pretillage haying by tillage interaction exhibited by organic $\mathrm{C}$ and total $\mathrm{N}$ are likely the result of an interaction between the physiological activity and amount of biomass present on the plots and the degree of incorporation and redistribution of this biomass within the soil during tillage. In a nearby cropping system study, Wienhold and Halvorson (1998) observed increasing total N and organic $\mathrm{C}$ contents as tillage intensity decreased. In this study, treatments that were hayed prior to tillage also exhibited increasing total $\mathrm{N}$ and organic $\mathrm{C}$ content as tillage intensity decreased (Table 4). Others have reported a similar trend between soil organic $\mathrm{C}$ and tillage intensity suggesting that this may be a general trend for soils in the northern Great Plains (Campbell et al., 1995). A similar pattern will likely emerge in the non-hayed plots of the current study as residue decomposition proceeds.

Soil $\mathrm{pH}$ in the 0 - to $0.05-\mathrm{m}$ depth of cropped soils exhibited a year $\times$ cropping practice interaction $(P=$ 0.001). Soil pH decreased from 6.57 in 1995 to 6.09 in 1997 in annually cropped plots but did not change in reference plots where the $\mathrm{pH}$ averaged across years was 6.61. Soil $\mathrm{pH}$ in the $0.05-$ to $0.15-\mathrm{m}$ depth of cropped soils also decreased from 6.19 in 1995 to 5.97 in 1997 $(P=0.001)$. While the changes in soil $\mathrm{pH}$ were of statistical significance they were not of agronomic significance as all $\mathrm{pH}$ values were within the range suitable for nutrient availability and plant growth (Prasad and Power, 1997). The EC in the 0- to 0.05-m depth was similar $\left(0.51 \mathrm{dS} \mathrm{m}^{-1}\right)$ across treatments while in the 0.05 - to $0.15-\mathrm{m}$ depth the EC increased from $0.29 \mathrm{dS} \mathrm{m}^{-1}$ in 1995 to $0.37 \mathrm{dS} \mathrm{m}^{-1}$ in $1997(P=0.02)$. Observed EC values were well below those indicative of saline conditions and are within the range for favorable plant growth (Maas, 1986).

\section{Biological Attributes}

The number of culturable fungi was similar across treatments in both the 0 - to $0.05-\mathrm{m}\left(32.5 \times 10^{9} \mathrm{~m}^{-2}\right)$ and 0.05 - to $0.15-\mathrm{m}\left(49.2 \times 10^{9} \mathrm{~m}^{-2}\right)$ depths. The number of culturable bacteria in the 0 - to $0.5-\mathrm{m}$ depth differed among the cropping practice treatments $(P=$ $0.0002)$. The number of culturable bacteria were higher in the reference treatments $\left(14.2 \times 10^{12} \mathrm{~m}^{-2}\right)$ than in the annually cropped treatments where the number of culturable bacteria increased as tillage intensity decreased $\left(6.7 \times 10^{12} \mathrm{~m}^{-2}\right.$ under CT, $9.8 \times 10^{12} \mathrm{~m}^{-2}$ under MT, and $9.9 \times 10^{12} \mathrm{~m}^{-2}$ under NT). In the 0.05 - to $0.15-\mathrm{m}$ depth the number of culturable bacteria increased from $10.3 \times 10^{12} \mathrm{~m}^{-2}$ in 1995 to $17.5 \times 10^{12} \mathrm{~m}^{-2}$ in 1997 $(P=0.0004)$. In the 0 - to $0.05-\mathrm{m}$ depth, the number of culturable actinomycetes were similar across treatments $\left(8.1 \times 10^{12} \mathrm{~m}^{-2}\right)$. The number of culturable actinomycetes in the 0.05 - to $0.15-\mathrm{m}$ depth increased from $10.9 \times$ $10^{12} \mathrm{~m}^{-2}$ in 1995 to $13.9 \times 10^{12} \mathrm{~m}^{-2}$ in $1997(P=0.01)$. The number of culturable actinomycetes were greater in the non-hayed treatments than in hayed treatments 
Table 5. Microbial biomass $\mathrm{C}$ in the 0.05 - to $0.15-\mathrm{m}$ depth averaged across $\mathbf{N}$ fertilizer treatments as a function of pre-tillage haying treatment, cropping practice, and time.

\begin{tabular}{|c|c|c|c|c|c|}
\hline \multirow[b]{2}{*}{ Haying treatment } & \multirow[b]{2}{*}{ Year } & \multicolumn{4}{|c|}{ Cropping practice $\dagger$} \\
\hline & & $\mathbf{C T}$ & MT & NT & Reference \\
\hline & & \multicolumn{4}{|c|}{ — Microbial biomass $\mathrm{C}\left(\mathrm{kg} \mathrm{ha}^{-1}\right)$} \\
\hline \multirow[t]{2}{*}{ Hayed } & 1995 & 142a才I & $317 \mathbf{a}$ & 251a & 240a \\
\hline & 1997 & 338a" & 302a & 335a & 271a \\
\hline \multirow{2}{*}{ Non-hayed } & 1995 & $695 \mathrm{~b}$ & $406 a$ & 232a & 244a \\
\hline & 1997 & 220a & 274a & 222a & 348a \\
\hline
\end{tabular}

† CT annual cropping with conventional tillage, MT annual cropping with minimum tillage, NT annual cropping with no-tillage, reference maintained in perennial vegetation.

II Year by hay be cropping practice interaction $(P=0.0007)$. Means within a row followed by a different letter are significantly different at $P=0.05$.

$\left(14.5 \times 10^{12} \mathrm{~m}^{-2}\right.$ vs. $\left.10.4 \times 10^{12} \mathrm{~m}^{-2}, P=0.02\right)$. The number of culturable actinomycetes were greater in the annually cropped MT treatment $\left(15.1 \times 10^{12} \mathrm{~m}^{-2}\right)$ than in the other cropping practices $\left(13.4 \times 10^{12} \mathrm{~m}^{-2}\right.$ in the reference treatment, $11.1 \times 10^{12} \mathrm{~m}^{-2}$ under $\mathrm{CT}$, and $10.1 \times 10^{12} \mathrm{~m}^{-2}$ under NT, $\left.P=0.03\right)$. In the 0 - to $0.05-\mathrm{m}$ depth, actinomycete and bacteria responded similarly to tillage intensity in 1995, increasing as tillage intensity decreased. In 1997, numbers of actinomycetes were similar across tillage treatments and the difference in numbers of bacteria across tillage treatments had lessened. The relationship between microorganism numbers and cropping practices emerging in this study are similar to those observed in a nearby cropping system study where actinomycete and bacteria numbers were similar across tillage treatments (Wienhold and Halvorson, 1998).

Microbial biomass $\mathrm{C}$ in the 0 - to $0.05-\mathrm{m}$ depth was similar across treatments $\left(226 \mathrm{~kg} \mathrm{ha}^{-1}\right)$. In the 0.05 - to 0.15-m depth microbial biomass $\mathrm{C}$ exhibited a year $\times$ pretillage haying $\times$ cropping practice interaction (Table 5). In 1995, microbial biomass $\mathrm{C}$ was similar across cropping practices that had been hayed while in non-hayed treatments microbial biomass $\mathrm{C}$ was greater under CT than under the other cropping practice treatments ( $\mathrm{Ta}-$ ble 5). In 1997, microbial biomass $C$ was similar across cropping practices in both hayed and non-hayed treatments (Table 5). Microbial biomass $\mathrm{N}$ in the $0-$ to $0.05-\mathrm{m}$ depth was similar across treatments $\left(21.7 \mathrm{~kg} \mathrm{ha}^{-1}\right)$. In the 0.05 - to $0.15-\mathrm{m}$ depth microbial biomass $\mathrm{N}$ exhibited a year $\times$ pretillage haying interaction $(P=0.04)$. In
1995, microbial biomass $\mathrm{N}$ was similar across haying treatments $\left(19.0 \mathrm{~kg} \mathrm{ha}^{-1}\right)$. In 1997, microbial biomass $\mathrm{N}$ was higher in hayed treatments $\left(46.0 \mathrm{~kg} \mathrm{ha}^{-1}\right)$ than in non-hayed treatments $\left(20.0 \mathrm{~kg} \mathrm{ha}^{-1}\right)$. From 1995 to 1997, microbial biomass $\mathrm{N}$ increased in hayed plots (from 13.2-46.0 kg ha ${ }^{-1}$ ) and did not change in nonhayed plots $\left(24.8 \mathrm{~kg} \mathrm{ha}^{-1}\right.$ in 1995 vs. $20.0 \mathrm{~kg} \mathrm{ha}^{-1}$ in 1997).

Soil microbial biomass $\mathrm{C}$ in the 0 - to $0.05-\mathrm{m}$ depth declined from 1995 to 1997 as did soil organic C. Soil microbial biomass $\mathrm{C}$ and soil organic $\mathrm{C}$ both exhibited pretillage haying $\times$ tillage interactions (Tables 3 and 5) but were not well correlated $(R=0.31$ in the 0 - to $0.05-\mathrm{m}$ depth and $R=0.23$ in the 0.05 - to $0.15-\mathrm{m}$ depth). The lack of correlation is due to the magnitude of the changes exhibited by these attributes. While soil microbial biomass declined three-fold from 1995 to 1997 soil organic C decreased 10\%. Soil microorganism numbers and biomass will continue to change as residue decomposition proceeds with new patterns emerging that are dependent on crop residue quantity and quality with availability of these residues differing with tillage intensity (Biederbeck et al., 1984; Janzen, 1987; Campbell et al., 1989).

Potentially mineralizable $\mathrm{N}$ in the 0 - to $0.05-\mathrm{m}$ depth of cropped soils exhibited a year $\times$ pretillage haying $\times$ cropping practice interaction (Table 6). In 1995, potentially mineralizable $\mathrm{N}$ in hayed plots was similar across cropping practices while in non-hayed plots potentially mineralizable $\mathrm{N}$ was greater under $\mathrm{CT}$ than under the other cropping practices (Table 6). In 1997, potentially mineralizable $\mathrm{N}$ in the hayed reference treatments was similar to that in hayed annually cropped treatments while within the hayed annually cropped treatments potentially mineralizable $\mathrm{N}$ increased as tillage intensity decreased (Table 6). In 1997, potentially mineralizable $\mathrm{N}$ was similar across cropping practices in non-hayed treatments (Table 6). Potentially mineralizable $\mathrm{N}$ in the 0.05 - to $0.15-\mathrm{m}$ depth was similar across treatments (135 $\left.\mathrm{kg} \mathrm{ha}^{-1}\right)$.

The mineralization rate constant $(k)$ in the 0 - to 0.05-m depth exhibited a year $\times$ pretillage haying $\times$ cropping practice interaction (Table 6). In 1995, $k$ was similar across cropping practices in the hayed treatment,

Table 6. Potentially mineralizable $\mathrm{N}\left(\mathrm{N}_{0}\right)$ and mineralization rate constant $(k)$ in the 0 to $0.05 \mathrm{~m}$ depth averaged across $\mathrm{N}$ fertilizer treatments as a function of pretillage haying treatment, cropping practice, and time.

\begin{tabular}{|c|c|c|c|c|c|}
\hline \multirow[b]{2}{*}{ Haying treatment } & \multirow[b]{2}{*}{ Year } & \multicolumn{4}{|c|}{ Cropping practice $\dagger$} \\
\hline & & CT & MT & NT & Reference \\
\hline & & & & & \\
\hline \multirow[t]{2}{*}{ Hayed } & 1995 & $80 \mathrm{a}$ T & $124 a$ & 91a & $97 \mathbf{a}$ \\
\hline & 1997 & $69 a$ & 110ab & $156 b$ & 127ab \\
\hline \multirow[t]{2}{*}{ Non-hayed } & 1995 & 279a & $68 \mathrm{~b}$ & $99 b$ & $95 \mathrm{~b}$ \\
\hline & 1997 & $76 a$ & 131a & $124 a$ & $107 a$ \\
\hline \multirow[t]{2}{*}{ Hayed } & 1995 & $0.204 a \S$ & $0.196 a$ & $0.205 a$ & $0.246 \mathrm{a}$ \\
\hline & 1997 & $0.129 a$ & $0.149 a$ & $0.097 \mathrm{a}$ & $0.122 a$ \\
\hline \multirow[t]{2}{*}{ Non-hayed } & 1995 & $0.080 \mathrm{a}$ & $0.429 b$ & $0.217 \mathbf{a}$ & $0.225 a b$ \\
\hline & 1997 & $0.284 a$ & $0.145 a$ & $0.147 a$ & $0.135 a$ \\
\hline
\end{tabular}

$\dagger$ CT annual cropping with conventional tillage, MT annual cropping with minimum tillage, NT annual cropping with no-tillage, reference maintained in perennial vegetation.

$\S$ Year by hay by cropping practice interaction $(P=0.03)$. Means within a row followed by a different letter are significantly different at $P=0.05$. II Year by hay by cropping practice interaction $(P=0.03)$. Means within a row followed by a different letter are significantly different at $P=0.05$. 
was greater under MT than under CT or NT in nonhayed treatments, and was similar in the reference treatment to that in annually cropped treatments in the nonhayed treatments (Table 6). In 1997, $k$ was similar across cropping practices in hayed and non-hayed treatments. In the 0.05 - to 0.15 -m depth $k$ exhibited a year $\times$ cropping practice interaction $(P=0.04)$. In $1995, k$ was similar across annually cropped treatments $\left(0.158 \mathrm{wk}^{-1}\right.$ under CT, $0.166 \mathrm{wk}^{-1}$ under MT, and $0.213 \mathrm{wk}^{-1}$ under NT) while $k$ was lower in the reference treatment $(0.120$ $\mathrm{wk}^{-1}$ ) than in the NT treatment. In 1997, $k$ was similar across cropping practices $\left(0.134 \mathrm{wk}^{-1}\right.$ under CT, 0.117 $\mathrm{wk}^{-1}$ under MT, $0.111 \mathrm{wk}^{-1}$ under NT, and $0.142 \mathrm{wk}^{-1}$ in reference treatments).

In 1997, potentially mineralizable $\mathrm{N}$ increased as tillage intensity decreased in the pretillage hayed treatment of the present study, a pattern similar to that observed in a nearby cropping system study (Wienhold and Halvorson, 1999). In addition, potentially mineralizable $\mathrm{N}$ in the 0.05 - to $0.15-\mathrm{m}$ depth increased $20 \%$ from 1995 to 1997 likely due to a lowering of the $\mathrm{C}: \mathrm{N}$ ratio resulting from residue decomposition. Annual cropping combined with conservation tillage has been shown to increase potentially mineralizable $\mathrm{N}$ when compared to crop-fallow with conventional tillage (Carter and Rennie, 1982; Wienhold and Halvorson, 1999).

Soil biological activity is largely controlled by physical and chemical conditions in the soil resulting from management practices such as tillage and residue management (Doran and Linn, 1994). In this study, the patterns exhibited by numbers of culturable microorganisms, microbial biomass $\mathrm{C}$, and potentially mineralizable $\mathrm{N}$ in 1995 resulted from differences in the quantity and quality of residue made available to soil microorganisms with the pretillage haying and tillage practices used. By 1997, much of the initial residue had decomposed and the response to tillage of the various biological attributes had changed, becoming similar to those observed in nearby established cropping systems (Wienhold and Halvorson, 1998, 1999) and to those reported by others in the northern Great Plains (Biederbeck et al., 1984; Janzen, 1987; Campbell et al., 1989).

\section{CONCLUSIONS}

Our results suggest that residue management, through haying and tillage, during the conversion of land previously cropped in perennial vegetation back to crop production influences a wide range of soil attributes. Tillage and haying effects were detected after treatments were initiated in 1995 with further changes occurring from 1995 to 1997 . The magnitude of these changes will determine to what extent gains made in soil and water conservation and $\mathrm{C}$ sequestration with perennial vegetation will be maintained after converting a site back to crop production.

A major challenge in converting land under perennial vegetation to crop land is managing the large amount of plant residue that may have accumulated. This residue must be managed in such a way that a seedbed is produced and soil and water resources are conserved
(Lindstrom et al., 1994). Our results suggest that once the accumulated residue has decomposed many of the soil attributes will respond to cropping practices in a predictable way. After two growing seasons soil properties in plots hayed prior to initial tillage responded to tillage in a similar way as those observed in a nearby cropping system study (Wienhold and Halvorson, 1998, 1999) and as those reported by others in the northern Great Plains (Biederbeck et al., 1984; Janzen, 1987; Campbell et al., 1989, 1995). In non-hayed plots, where larger amounts of residue were present when cropping was initiated, similar patterns have not emerged. The rapid establishment of predictable relationships between soil properties and implemented tillage and fertilizer management practices is desirable since it is only after the establishment of these relationships that accurate management decisions can be made. In this study we found that haying and use of conservation tillage facilitated the rapid establishment of well known relationships between soil properties and management practices while maintaining surface residues that are effective in conserving soil and water resources. Such an approach will allow producers to utilize annual cropping, fertilization, and conservation tillage practices that have been developed for this region.

\section{ACKNOWLEDGMENTS}

The authors thank Jason Gross for maintaining the field site; Larry Renner, Gary Brucker, and Mary Kay Tokach for laboratory analysis; and Keith and Lyle Boehm for providing access to the site.

\section{REFERENCES}

Arshad, M.A., B. Lowery, and B. Grossman. 1996. Physical tests for monitoring soil quality. p. 123-141. In J.W. Doran and A.J. Jones (ed.) Methods for assessing soil quality. SSSA Spec. Publ. 49. SSSA, Madison, WI

Biederbeck, V.O., C.A. Campbell, and R.P. Zentner. 1984. Effect of crop rotation and fertilization on some biological properties of a loam in southwestern Saskatchewan. Can. J. Soil Sci. 64:355-367.

Black, A.L., and D.L. Tanaka. 1997. A conservation tillage-cropping system study in the northern Great Plains of the United States. p. 335-341. In E.A. Paul et al. (ed.) Soil organic matter in agroecosystems: Long-term experiments in North America. CRC Press, Boca Raton, FL.

Blake, G.R., and K.H. Hartge. 1986. Bulk density. p. 363-375. In A. Klute (ed.) Methods of soil analysis Part 1: Physical and mineralogical methods. 2nd ed. ASA, Madison, WI.

Bruulsema, T.W., and J.M. Duxbury. 1996. Simultaneous measurement of soil microbial nitrogen, carbon, and carbon isotope ratio. Soil Sci. Soc. Am. J. 60:1787-1791.

Campbell, C.A., V.O. Biederbeck. M. Schnitzer, B. Selles, and R.P Zentner. 1989. Effect of 6 years of zero tillage and $\mathrm{N}$ fertilizer management on changes in soil quality of an orthic brown chernozem. Soil Tillage Res. 14:39-52.

Campbell, C.A., B.G. McConkey, R.P. Zentner, F.B. Dyck, F. Selles, and D. Curtin. 1995. Carbon sequestration in a brown chernozem as affected by tillage and rotation. Can. J. Soil Sci. 75:449-458.

Carter, M.R., and D.A. Rennie. 1982. Changes in soil quality under zero tillage farming systems: distribution of microbial biomass and mineralizable C and N potentials. Can. J. Soil Sci. 62:587-597.

Dhuyvetter, K.C., C.R. Thompson, C.A. Norwood, and A.D. Halvorson. 1996. Economics of dryland cropping systems in the Great Plains. J. Prod. Agric. 9:216-222.

Doran, J.W. 1980. Soil microbial and biochemical changes associated with reduced tillage. Soil Sci. Soc. Am. J. 44:765-771. 
Doran, J.W., and D.M. Linn. 1994. Microbial ecology of conservation management systems. p. 1-27. In J.L. Hatfield and B.A. Stewart (ed.) Soil biology: Effects on soil quality. Lewis Publ., Boca Raton, FL.

Janzen, H.H. 1987. Soil organic matter characteristics after long-term cropping to various spring wheat rotations. Can. J. Soil Sci. 67:845856.

Jenny, H. 1980. The soil resource: Origin and behavior. SpringerVerlag, New York.

Jenkinson, D.S., and D.S. Powlson. 1976. The effects of biocidal treatments on metabolism in soil: I. Fumigation with chloroform. Soil Biol. Biochem. 8:167-177.

Lindstrom, M.J., T.E. Schumacher, and M.L. Blecha. 1994. Management considerations for returning CRP lands to crop production. J. Soil Water Conserv. 49:420-425.

Linn, D.M., and J.W. Doran. 1984. Effect of water-filled pore space on carbon dioxide and nitrous oxide production in tilled and nontilled soils. Soil Sci. Soc. Am. J. 48:1267-1272.

Littell, R.C., G.A. Milliken, W.W. Stroup, R.D. Wolfinger. 1996. SAS system for mixed models. SAS Institute, Inc., Cary, NC.

Low, A.J. 1972. The effect of cultivation on the structure and other physical characteristics of grassland and arable soils. J. Soil Sci. 23:363-380.

Lowery, B., W.J. Hickey, M.A. Arshad, and R. Lal. 1996. Soil water parameters and soil quality. p. 143-155. In J.W. Doran and A.J. Jones (ed.) Methods for assessing soil quality. SSSA Spec. Publ. No. 49. SSSA, Madison, WI.

Maas, E.V. 1986. Salt tolerance of plants. Appl. Agric. Res. 1:12-26.

McLean, E.O. 1982. Soil pH and lime requirement. p. 199-224. In A.L. Page et al. (ed.) Methods of soil analysis Part 2: Chemical and microbial properties. 2nd ed. ASA, Madison, WI.
Mulvaney, R.L. 1996. Nitrogen - Inorganic forms. p. 1123-1184 In D.L. Sparks et al. (ed.) Methods of soil analysis Part 3: Chemical methods. SSSA Book Series 5. ASA, Madison, WI.

Norwood, C. 1994. Profile water distribution and grain yield as affected by cropping system and tillage. Agron. J. 86:558-563.

Peterson, G.A., A.J. Schlegel, D.L. Tanaka, and O.R. Jones. 1996. Precipitation use efficiency as affected by cropping and tillage systems. J. Prod. Agric. 6:261-266.

Prasad, R., and J.F. Power. 1997. Soil Fertility Management for Sustainable Agriculture. CRC Lewis Publishers, Boca Raton, FL.

Rhoades, J.D. 1982. Soluble salts. p. 167-179. In A.L. Page et al. (ed.) Methods of soil analysis Part 2: Chemical and microbial properties. 2nd ed. ASA, Madison, WI.

Schepers, J.S., D.D. Francis, and M.T. Thompson. 1989. Simultaneous determination of total $\mathrm{C}$, total $\mathrm{N}$, and ${ }^{15} \mathrm{~N}$ on soil and plant material. Commun. Soil Sci. Plant Anal. 20:949-959.

Stanford, G., and S.J. Smith. 1972. Nitrogen mineralization potential of soils. Soil Sci. Soc. Am. Proc. 36:465-472.

Stevenson, F.J. 1986. Cycles of soil carbon, nitrogen, phosphorus, sulfur, micronutrients. John Wiley and Sons, New York.

Wienhold, B.J., and A.D. Halvorson. 1998. Cropping system influences on several soil quality attributes in the Northern Great Plains. J. Soil Water Conserv. 53:254-258.

Wienhold, B.J., and A.D. Halvorson. 1999. Nitrogen mineralization responses to cropping, tillage, and nitrogen rate in the Northern Great Plains. Soil Sci. Soc. Am. J. 63:192-196.

Wienhold, B.J., and D.L. Tanaka. 2000. Haying, tillage, and nitrogen fertilization influences on infiltration rates at a conservation reserve program site. Soil Sci. Soc. Am. J. 64:379-381.

Wollum, A.G., II. 1982. Cultural methods for soil microorganisms. p 781-802. In A.L. Page et al. (ed.) Method of Soil anlysis Part 2: Chemical and microbial properties. 2nd ed. ASA, Madison, WI. 